TITLE:

\title{
NIPPONOMONTACUTA ACTINARIOPHILA Gen. et Sp. Nov., A NEW COMMENSAL BIVALVE OF THE SEA ANEMONE
}

\author{
AUTHOR(S): \\ Yamamoto, Torao; Habe, Tadashige
}

CITATION:

Yamamoto, Torao .... [et al]. NIPPONOMONTACUTA ACTINARIOPHILA Gen. et Sp. Nov., A NEW COMMENSAL BIVALVE OF THE SEA ANEMONE. PUBLICATIONS OF THE SETO MARINE BIOLOGICAL LABORATORY 1961, 9(2): 265-266

ISSUE DATE:

1961-12-20

URL:

http://hdl.handle.net/2433/175292

RIGHT: 


\title{
NIPPONOMONTACUTA ACTİNARIOPHILA Gen. et Sp. Nov.,
}

\section{A NEW COMMENSAL BIVALVE OF THE SEA ANEMONE ${ }^{1)}$}

\author{
ToRao YAMAMOTO and TADAShige HABE \\ Seto Marine Biological Laboratory (Kyoto University) and Amakusa Marine \\ Biological Laboratory (Kyushu University)
}

With 2 Tex-figures

Last summer, a small bivalve was collected by the senior author from the surface of the sea anemone whose scientific name was not yet determined, on the rocky shore near the Seto Marine Biological Laboratory and the commensal habit of this interesting bivalve has been observed by him. This is new to science. Therefore this is described on the following lines.

\section{Nipponomontacuta actinariophila gen. et sp. nov.}

(Text-figs. 1, 2)

Shell small, ovate in shape, inequilateral, the anterior half somewhat smaller and narrower than the posterior, but equivalve, reddish rose in colour, especially deeply coloured in the umbonal area; each valve moderately convex and umbo slightly prominent beyond the dorsal margin and somewhat prosogyrate; dorsal margin nearly straight; anterior dorsal margin shorter than the posterior; anterior margin roundly arcuated and the posterior subtrucated; the ventral gently curved; surface covered with the rough brownish yellow periostracum which is deciduous at the umbonal area and marks several radial cords from the umbo to the anteroventral margin and sculptured with the growth lines which sometimes become strong as the resting stages; hinge plate rather thick and broad; hinge of the left valve with two stout diverging teeth, the anterior tooth shorter and stronger than the posterior, between them a resilifer present; in the right valve the extension of the dorsal margin is fixed the pits between the cardinal teeth and the anterior and posterior dorsal margins in the left valve; mantle line connected the anterior muscle scar with the posterior is simple, not present any sinuation

1) Contributions from the Seto Marine Biological Laboratory, No. 370 and Contributions from the Amakusa Marine Biological Laboratory (Kyushu University), No. 157.

Publ. Seto Mar. Biol. Lab., IX (2), 1961. (Article 14) 
at the posterior end; ventral margin flat and not crenulated.

Length $4.0 \mathrm{~mm}$, height $3.0 \mathrm{~mm}$, breadth $1.8 \mathrm{~mm}$ (conjoined type specimen)

Length $4.1 \mathrm{~mm}$, height $3.1 \mathrm{~mm}$, breadth $0.9 \mathrm{~mm}$ (left valve collected from off Tomioka, Amakusa, Kumamoto Pref., Kyushu)

Type locality: Bansyo-zaki, Shirahama, Wakayama Pref., Honshu.

Remarks: A new genus, Nipponomontacuta, established for this interesting species, resembles Montacuta Turton, but the former has the ovate shell the umbo of which is situated nearly midway between the anterior and dorsal margins
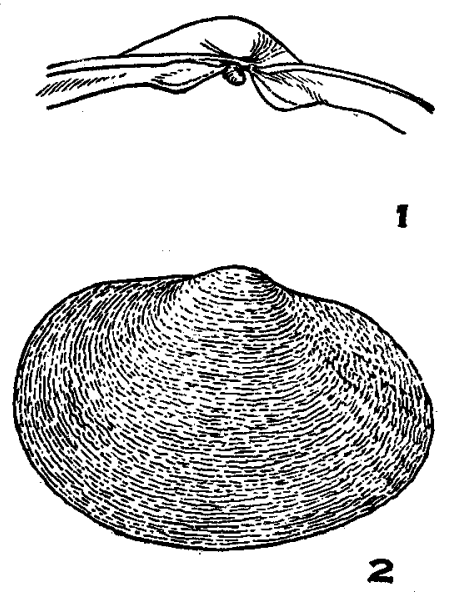

Figs. 1, 2. Nipponomontacuta actinariophila gen. et sp. nov.

1. hinge teeth in the left valve, 2. right valve.

and with the very stout cardinal teeth in the left valve and the interior is surrounded by the narrow flat margin. Moreover, theshell is covered by the rough thick periostracum. In the genus, Montacutona $\mathrm{HABE}$, the surfuce of the shell is smooth and the umbo is oblique forwards and is rather nearer to the anterior than to the posterior end.

\section{LITERATURE CITED}

HABE, T. 1915 1959. Publ. Seto Mar. Biol. Lab., 7 (2), 291-294.

Sars, G. O. 1878. Mollusca Regionis Arcticae Norvegiae.

THIELE, J. 1934. Handbuch der Syst. Weichtierkunde, 2, 782-948.

Yamamoto, G. and Habe T. 1959. Bull. Mar. Biol. Stat. Asamushi, 9 (3), 85-122. 